\title{
Variation of soil and plant characteristics among old world bluestem species
}

\author{
Ted M. Zobeck ${ }^{1^{*}}$, Vivien G. Allen ${ }^{2}$, Jenny Jo Cox ${ }^{1,2}$, Dirk Philipp $^{3}$ \\ ${ }^{1}$ USDA-ARS, Cropping Systems Research Lab, Lubbock, TX, USA; \\ ${ }^{2}$ Department of Plant and Soil Science, Texas Tech University, Lubbock, TX, USA; \\ ${ }^{3}$ University of Arkansas, Fayetteville, AR, USA; ${ }^{*}$ Corresponding Author: ted.zobeck@ars.usda.gov
}

Received 21 March 2011; revised 29 May 2011; accepted 29 July 2011.

\begin{abstract}
Old world bluestems (Bothriochloa spp.) have been successfully introduced as grasses for livestock forage in the semiarid Texas High Plains. Questions remain, however, on effects of these grasses on soil resources. We tested the hypothesis that differences in grass species produce differences in soil properties important to crop growth and useful in selecting the optimum species for the Southern High Plains of Texas. Three old world bluestem (Bothriochloa) species [C.E. Hubbard 'Caucasian', B. caucasica (Trin.); 'WW Spar', B. ischaemum (L.) Keng. var ischaemum (Hack.); and S.T. Blake 'WW-B Dahl', B. bladhii (Retz)] were grown in a randomized complete block design, with three replications, for nine years on a clay loam soil near Lubbock, Texas. Soil samples were collected in the ninth year to determine soil texture, wet aggregate stability, bulk density (BD), soil organic carbon (SOC), particulate organic carbon (POC), and soil strength as measured by the cone pentrometer. The grass species differed in their above-ground biomass and belowground root production. In the ninth year of production, Bothriochloa caucasica and $B$. bladhii produced about twice the above-ground biomass with about $25 \%$ fewer roots than $B$. ischaemum. Soils where $B$. caucasica was grown had the highest BD $\left(1.36 \mathrm{mg} \mathrm{m}^{-3}\right)$ and $B$. ischaemum had the lowest $\left(1.31 \mathrm{mg} \mathrm{m}^{-3}\right)$. The soil in which $B$. ischaemum was growing had a lower BD, greatest root biomass, organic matter content, and aggregate stability suggesting superior soil quality for agricultural production. The species $B$. bladhii, however, often exhibited soil properties that were similar to both other species tested. Since Bothriochloa bladhii had
\end{abstract}

superior or similar soil properties for plant growth among the species tested and has been shown to be higher in forage quality, animal performance, and carrying capacity than the other species, it appears to be the best choice among these three species to optimize both animal performance and desirable soil properties.

Keywords: Old World Bluestem; Soil Quality; Grasses; Soil Organic Carbon

\section{INTRODUCTION}

Old world bluestems (Bothriochloa spp.) have been among the more successful grasses for livestock feed in the semiarid Texas High Plains [1]. Research has suggested that the nutritive value of old world bluestems is influenced by species, environmental conditions, management, and physiographic location [1-3]. The Southern High Plains is a semiarid region, often subject to extended periods with little rainfall, producing drought stress in plants. Studies of B. caucasica and B. ischaemum comparing growth characteristics during periods of abundant and restricted water availability suggested that B. caucasica has a lower drought performance potential relative to $B$. ischaemum [4-6]. Bothriochloa caucasica and $B$. ischaemum have had a relatively long history on the Southern High Plains, compared with the relatively recently released B. bladii [7]. Recent studies comparing the three species have shown that, in general, B. bladii provided greater mineral concentrations to grazing animals than either B. caucasica or B. ischaemum [8]. In addition, $B$. bladii has been recently used in an integrated crop-livestock system and shown to provide at least or above average levels of animal performance and profitability [9]. Questions, however, remain on the effect of the grasses on the soil resources.

Grasses or other forages have distinct effects on soil 
physical and chemical properties. Grasses and forages provide organic matter to the soil as the roots and surface plant matter die and decompose. Organic matter in soil improves soil structure as well as the ability of soil to hold nutrients and water [10]. Soils under continuous plant cover tend to have a greater amount of associated $\mathrm{C}$ than tilled or bare soils [11]. Plots with grasses had significantly greater organic matter and favorable physical conditions than weedy plots [12]. Tillage of crops often greatly reduces soil organic carbon (SOC), whereas no-till systems help maintain and even increase SOC [13-15].

The particulate organic matter (POM) fraction of soils is comprised of large particles of organic matter (250 $2000 \mu \mathrm{m})$ that exists as free organic matter or that is encrusted with soil particles, which in turn offers protection from decomposition [16]. The carbon content of $\mathrm{POM}$ is often referred to as particulate organic carbon (POC). Particulate organic carbon seems to be more sensitive to changes in management practices than total SOC $[17,18]$ and has been found to be higher in native sods than cropped soils [17,19]. Increasing POC has been associated with improved soil quality for plant growth [20] and related to other soil and plant properties such as nutrient mineralization, vegetation type, and tillage practices [18].

Grass sods and forage crops have been shown to be effective in improving soil structural stability [21]. Grasses have fibrous root systems provide both chemical and physical benefits to aggregate stability through production of chemical binding agents such as carbonates as well as physically binding roots to the soil particles [16, $22,23]$. Grass root growth increases aggregation through the mesh-like network of root hairs and fungal hyphae [24]. These root systems are beneficial even after the plant dies, providing organic matter to the soil, and leaving spaces for water infiltration. In addition, organic matter on the surface of a soil may prevent crusting, increasing water infiltration rates. Water infiltration was found to be higher on a grass-covered soil than on a tilled soil [25]. However, the effect of root biomass on aggregate stability is not always clear. Soils with grass swards have been shown to provide greater aggregate stability than when in crops such as corn (Zea mays L.) and soybean [Glycine max (L.) Merr.] [26]. Nevertheless, root biomass has also been shown to have little or no effect on aggregate stability [27].

Root proliferation affects bulk density (BD) and soil strength, as well. In densely compacted soils, roots grow into cracks in the hard layers [28], and BD is decreased over time by the expansion of roots. For example, the $\mathrm{BD}$ of soils with perennial grass cover for 15 years decreased more than soils in annual cropping over the same time period [29]. Bulk density also differs with depth [30]. The bulk density in the top $5 \mathrm{~cm}$ of a perennial grass-covered soil was significantly less than at depths below $5 \mathrm{~cm}$ [31]. The resistance of soil to penetration by a cone-tipped rod, known as the penetration resistance, is a measure of soil strength and is often related to bulk density. The penetration resistance was greater for grass-covered soil than cultivated [32] or bare, uncultivated soil [33].

Recent studies on the relative benefits of three old world bluestem species have explored several qualities of these grasses, including influence of irrigation on production, water use efficiency, forage nutritive value, and morphology $[1,8,34]$. We investigated the effects of these different grass species on selected soil properties in the Southern High Plains of Texas. Characteristics explored were aboveground plant biomass, root biomass, soil surface texture and moisture content, total SOC and POC content, soil strength, bulk density, water infiltration rate, and large ( $<8 \mathrm{~mm}$ diameter) and small (1 to 2 $\mathrm{mm}$ diameter) wet aggregate stability. We tested the hypothesis that differences in old world bluestem grass species produce differences in these surface soil properties important to crop growth.

\section{MATERIALS AND METHODS}

\subsection{Study Site}

This work was part of a larger irrigation study testing the effects of four water irrigation treatments (dryland, low, medium, and high) on three old world bluestem (Bothriochloa) species (C.E. Hubbard 'Caucasian', B. caucasica [Trin.]; 'WW Spar', B. ischaemum [L.] Keng. var ishaemum [Hack.]; and S.T. Blake 'WW-B Dahl', B. bladhii [Retz]) (Philipp et al., 2005). The site was located in northeast Lubbock County, Texas $\left(101^{\circ} 47^{\prime} \mathrm{W}\right.$; $33^{\circ} 45^{\prime} \mathrm{N}$; $993 \mathrm{~m}$ elevation). The area has a semiarid climate with a mean annual precipitation of $470 \mathrm{~mm}$ and an average air temperature of $15.5^{\circ} \mathrm{C}$.

Each species was replicated three times in a randomized complete block design. The grasses were established in 1996 and were used in a lamb (Ovis aris) grazing experiment from 1998 to 2000 [35] prior to the irrigation study. Prior to 1996 the site was disked and planted to various forage species. Grazing ended in September 2000. The irrigation study was conducted for three years, 2001 through 2003 [7]. After termination of the irrigation study in 2003, no further irrigation or fertilizer was applied. Plots were mowed once in midsummer each year and above-ground biomass removed as hay in 2004. All plots were mowed in late winter to remove residual herbage before spring growth. Samples used in the current study were collected in the summer 
of 2005, two years after the end of the irrigation study. Due to experimental limitations, only the medium water treatment plots were used in our study. The amount of water applied in the medium water treatment during the irrigation study was $66 \%$ replacement of potential evapotranspiration (PET) [36] minus precipitation. Irrigation was applied through a surface drip irrigation system.

Each plot was $10 \mathrm{~m}$ by $15 \mathrm{~m}$. The soil series was Pullman sandy clay loam (fine, mixed, superactive, thermic Torrertic Paleustoll) on a nearly level ( $0 \%-1 \%$ slope) land surface. This soil is a very deep, well drained, slowly permeable soil formed in loamy sediments and occupies approximately 1.3 million ha ( 3.3 million ac) in the Southern High Plains of Texas and Oklahoma [37]. During the irrigation study (2001 to 2003), plots were fertilized equally to meet all soil test recommendations such that $\mathrm{N}$ and other nutrients were not limited. Details of precipitation, irrigation and fertilizer applied and application methods are described in Philipp et al. [1]. No water or nutrients were applied in 2004 and 2005. Precipitation during these two years was $807 \mathrm{~mm}$ for 2004 and $277 \mathrm{~mm}$ through mid-August 2005.

\subsection{Soil and Plant Sampling and Analyses}

Soil samples were collected from depths of $0-5 \mathrm{~cm}$ and $5-15 \mathrm{~cm}$ to determine soil texture, wet aggregate stability, BD, SOC, POC in June 2005. Soil samples were screened first through a 2-mm sieve and larger pieces of plant material were removed.

\subsubsection{Soil Physical Properties}

Soil texture was determined on sieved samples using a Beckman-Coulter LS230 [38] after dispersing the soil in $5 \mathrm{~g} \cdot \mathrm{L}^{-1}$ sodium hexametaphosphate by shaking overnight in a reciprocating shaker. Bulk density was determined using the soil core method [39]. Samples for BD (two samples from each replication) were collected using a 2-cm diameter push probe with care taken to ensure no compaction occurred during sampling. Soil BD was used to calculate SOC mass on an area basis. In-situ soil strength was measured to a depth of $0.3 \mathrm{~m}$ with an automated Bush penetrometer [40] (Soil Penetrometer SP1000, Findlay Irvine Ltd.) and observed at 1-cm intervals. The cone-shaped penetrometer tip used for these penetration resistance (PR) measurements had a $30^{\circ}$ angle and $12.6 \mathrm{~mm}$ diameter base. Fifteen PR measurements were randomly inserted in each plot. Statistical analyses of the soil strength tests were performed on the sum of the PR observations to a depth of $15 \mathrm{~cm}$. In addition, the PR was averaged for the $0-5 \mathrm{~cm}$ and $5-15 \mathrm{~cm}$ depths in order to compare with other properties also observed at these depths. Gravimetric soil water content was measured at the time of $\mathrm{PR}$ readings for the depths 0 $-5,5-10,10-15$, and $15-30 \mathrm{~cm}$ to determine interactions of water content and $\mathrm{PR}$ readings. Water infiltration was determined using a double-ring infiltrometer at two locations in each replication [41]. Wet aggregate stability was measured on duplicate subsamples of aggregates smaller than $8.0 \mathrm{~mm}$ in diameter to determine waterstable aggregate size distribution by wet sieving according the procedure of Kemper and Rosenau [42] and expressed as the mean weight diameter (MWD). Duplicate subsamples of aggregates 1.0 to $2.0 \mathrm{~mm}$ in diameter were sieved from a portion of the bulk soil. Wet aggregate stability was also measured on this 1.0 to $2.0 \mathrm{~mm}$ in diameter aggregates according to Kemper [43] and expressed as the percentage of aggregates (WAS2).

\subsubsection{Soil Chemical Properties}

The chemical properties observed in this study consisted of SOC and POC as measured as a concentration (mass per unit mass) by soil depth and mass per unit area. The measurements made on a mass per unit area basis were determined by summing the total amount of each constituent to a depth of $15 \mathrm{~cm}$. Sieved soil samples were used to determine POC according to the method of Gregorich and Ellert [44]. Twenty-five-gram subsamples of sieved samples were first dispersed in $100 \mathrm{~mL}$ of 5 $\mathrm{g} \cdot \mathrm{L}^{-1}$ sodium hexametaphosphate by shaking overnight in a reciprocating shaker. The dispersed soil that was retained on a $53 \mu \mathrm{m}$ sieve was dried overnight at $60^{\circ} \mathrm{C}$ before analysis for organic $\mathrm{C}$. These samples, along with twenty-five-gram subsamples of sieved samples used to determine SOC, were ground overnight in a roller-mill (consisting of round bottles with three metal rods inside to pulverize the samples) to a size passing a $150 \mu \mathrm{m}$ screen and analyzed for $\mathrm{C}$ content with an Elementar Vario Macro C-N analyzer (Elementar Americas, Inc., Mt. Laurel, NJ).

\subsubsection{Plant Biomass and Roots}

Plant biomass was determined by clipping a $1-\mathrm{m}^{2}$ plot in each replication of each species in August 2005. Plant biomass samples were dried at $60^{\circ} \mathrm{C}$ to a constant weight. Root mass was determined from six core samples collected in each grass species and replication with a $5-\mathrm{cm}$ diameter soil probe to a depth of $15 \mathrm{~cm}$.

\subsubsection{Statistical Analyses}

Statistical analyses were performed using procedures of SAS version 9.1 [45]. Analyses of variance (ANOVA) were performed with Proc Mixed using a randomized complete block with three replications as the model. Grass species was considered the main effect and the blocks were considered as a random effect. When depth 
was evaluated, the statistical design was a split-plot with depth as a subplot. Statistical differences were evaluated at the $P \leq 0.05$ level, with the exception of SOC concentration which was evaluated at the $P \leq 0.10$ level, as discussed later.

\section{RESULTS}

\subsection{Soil Physical Properties}

Sand and clay content of the surface revealed no significant differences among grass species; however, there were differences among depths (Table 1), but no interactions among grass species and depths. The surface $0-5$ $\mathrm{cm}$ contained more sand and less clay than the $5-15 \mathrm{~cm}$ layer. Among all grass species, the surface had 21.6\% clay and $54.4 \%$ sand and the second layer had $26.5 \%$ clay and $48.3 \%$ sand. Despite significant differences in the amount of clay and sand particles between depths, the texture for both depths was a sandy clay loam.

Although the surface 0 to $30 \mathrm{~cm}$ total soil water content, taken immediately prior to PR measurements, was not significantly different among grass species (Table 1), there was a slight difference in water content with depth. There were no interactions among grass species and depths. The surface $0-5 \mathrm{~cm}$ had significantly higher water content of about $30.5 \%$ while the other depthswere not significantly different and averaged about $23.0 \%$ soil water (Figure 1).

Soil strength measurements, as determined by PR, identify zones of resistance to an applied force. Figure 1 shows how PR differed among grass species and among depths within grass species, but the effect of species did not depend on depth (Table 1). The lowest strength was

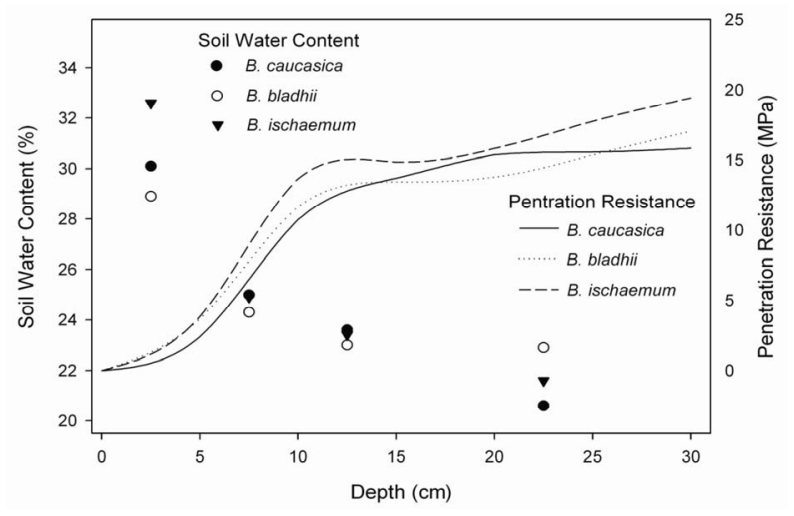

Figure 1. Soil water content and penetration resistance by grass species and depth.

Table 1. Differences among old world bluestem grass species for selected soil and plant properties.

\begin{tabular}{|c|c|c|c|c|c|c|c|c|c|}
\hline \multirow[b]{3}{*}{ Property } & & & & \multicolumn{2}{|c|}{ B. caucasica } & \multicolumn{2}{|c|}{ B. bladhii } & \multicolumn{2}{|c|}{ B. ischaemum } \\
\hline & \multicolumn{3}{|c|}{ Source of Variation } & \multicolumn{3}{|c|}{ Standard } & \multirow{2}{*}{$\begin{array}{c}\text { Standard } \\
\text { Error }\end{array}$} & \multirow[b]{2}{*}{ Mean } & \multirow{2}{*}{$\begin{array}{c}\text { Standard } \\
\text { Error }\end{array}$} \\
\hline & Depth (D) & Treatment $(\mathrm{T})$ & DxT & Mean & Error & Mean & & & \\
\hline Clay Content (\%) & $<0.0001$ & 0.3 & 0.6 & 24 & 0.7 & 24.9 & 0.7 & 23.3 & 0.7 \\
\hline Sand Content (\%) & 0.0004 & 0.3 & 0.6 & 51.3 & 1.1 & 50.2 & 1.1 & 52.6 & 1.1 \\
\hline Root Biomass $\left(\mathrm{kf} \cdot \mathrm{m}^{-3}\right)$ & N/A & 0.003 & $\mathrm{~N} / \mathrm{A}$ & $10.2 b$ & 1.06 & $11.6 \mathrm{~b}$ & 1.06 & $15.5 \mathrm{a}$ & 1.06 \\
\hline Soil Water Content (\%) & $<0.0001$ & 0.72 & 0.8 & 24.8 & 0.84 & 24.8 & 0.84 & 25.6 & 0.84 \\
\hline Penetration Resistance (Mpa) & N/A & 0.04 & N/A & $10.6 b$ & 0.5 & $11.3 \mathrm{ab}$ & 0.5 & $12.7 \mathrm{a}$ & 0.5 \\
\hline Bulk Density $\left(\mathrm{mg} \cdot \mathrm{m}^{-3}\right)$ & $<0.0001$ & 0.03 & 0.8 & $1.36 \mathrm{a}$ & 0.01 & $1.33 \mathrm{ab}$ & 0.01 & $1.31 \mathrm{~b}$ & 0.01 \\
\hline MWD (mm) & $<0.0001$ & $<0.0001$ & 0.04 & 5.16 & 0.11 & 5.04 & 0.1 & 5.67 & 0.11 \\
\hline WAS2 (\%) & 0.02 & 0.02 & 0.1 & $49.5 b$ & 2.88 & $51.4 \mathrm{ab}$ & 2.9 & $55.8 \mathrm{a}$ & 2.87 \\
\hline SOC Concentration $\left(\mathrm{g} \cdot \mathrm{kg}^{-1}\right)$ & $<0.0001$ & 0.03 & 0.05 & 14.3 & 0.6 & 15.7 & 0.6 & 16.5 & 0.6 \\
\hline SOC Mass $\left(\mathrm{MG} \cdot \mathrm{ha}^{-1}\right)$ & N/A & 0.09 & $\mathrm{~N} / \mathrm{A}$ & $26.7 b$ & 0.55 & $27.8 \mathrm{ab}$ & 0.55 & $28.8 \mathrm{a}$ & 0.55 \\
\hline POC Concentration $\left(\mathrm{g} \cdot \mathrm{kg}^{-1}\right)$ & $<0.0001$ & 0.005 & 0.02 & 5.89 & 0.37 & 8.06 & 0.37 & 7.95 & 0.37 \\
\hline POC Mass $\left(\mathrm{MG} \cdot \mathrm{ha}^{-1}\right)$ & N/A & 0.04 & N/A & $9.85 b$ & 0.63 & $12.54 \mathrm{a}$ & 0.63 & $12.5 \mathrm{a}$ & 0.63 \\
\hline
\end{tabular}

Notes: MWD-mean weight diameter; WAS2-wet aggregate stability for aggregates 1.0 - 2.0 mm diameter; SOC-soil organic carbon; POC-particulate organic matter carbon; C and POC mass (MG/ha) represent the total for the $0-15 \mathrm{~cm}$ depth; Mean clay and sand content, SOC concentration, MWD, WAS2, bulk density, and root mass were measured through a depth of $0-15 \mathrm{~cm}(0-5$ and $5-15 \mathrm{~cm}$ depth increments). Soil water content was measured through a depth of $0-30 \mathrm{~cm}$ ( 0 - 5, $5-10$, and $15-30 \mathrm{~cm}$ depth increments) and penetration resistance was totaled throughout the $0-15 \mathrm{~cm}$ depth. Significance levels for testing differences among grass species (Treatment) and soil depth (Depth) are indicated by lower case letters. Means within the row with the same letter for SOC mass (MG/ha) are not different among grass species $(P \leq 0.10)$. Means within the rows with the same letter for other comparisons among grass species are not different $(P \leq 0.05)$. Properties with no letter are not significantly different among grass species $(P>0.10)$ or have interactions of depth and grass species $($ DxT $)$. 
in the surface $0-5 \mathrm{~cm}$ and increased with soil depth as soil water content decreased (Figure 1). We observed significant differences soil strength among species when PR was summed over the $30 \mathrm{~cm}$ depth for each species and replication (Table 1). Bothriochloa ischaemum produced the greatest total resistance to the cone penetrometer and B. caucasica had the smallest total resistance. The PR observed in B. bladhii was not significantly different from either of the other grass species (Table 1). The mean PR was also determined for the $0-5 \mathrm{~cm}$ and 5 - $15 \mathrm{~cm}$ depths and PR by species. The surface $0-5 \mathrm{~cm}$ soil strength in the grasses was, on average, about one-fourth the strength found in the $5-15 \mathrm{~cm}$ layer. Averaged over all species, PR was $6.6 \mathrm{Mpa} \cdot \mathrm{cm}^{-1}(\mathrm{SE}=0.55)$ in the surface $0-5 \mathrm{~cm}$ and $26.0 \mathrm{Mpa} \cdot \mathrm{cm}^{-1}(\mathrm{SE}=0.55)$ in the $5-15 \mathrm{~cm}$ depth.

Another measure of soil compaction, BD, differed. among grass species and among depths within grass species, but the effect of species did not depend on depth (Table 1). Averaged over all species, BD was 1.25 $\mathrm{Mg} \cdot \mathrm{m}^{-3}(\mathrm{SE}=0.005)$ in the surface $0-5 \mathrm{~cm}$ and 1.41 $\mathrm{Mg} \cdot \mathrm{m}^{-3}(\mathrm{SE}=0.005)$ in the $5-15 \mathrm{~cm}$ depth. Bothriochloa caucasica had the highest BD $\left(1.36 \mathrm{Mg} \cdot \mathrm{m}^{-3}\right)$ and $B$. ischaemum had the lowest $\left(1.31 \mathrm{Mg} \cdot \mathrm{m}^{-3}\right)$. The bulk density observed in B. bladhii was not significantly different from either of the other grass species (Table 1).

The mean infiltration rate was $0.97 \mathrm{~cm} \cdot \mathrm{hr}^{-1}(\mathrm{SE}=$ 0.08). Water infiltration readings are very time consuming and variable. Although we made two water infiltration readings on each replication, the double ring infiltration method used in this study still produced significant variation. Given the variability of this method, statistical tests lacked power to be able to detect biologically significant differences.

Wet aggregate stability is a measure of the strength of bonding of individual soil particles into larger aggregates to withstand the force of disruption caused by agitation in water. Two measures of wet aggregate stability were tested; a measure of the stability of large aggregates less than $8 \mathrm{~mm}$ diameter, MWD, and a measure of the stability of smaller 1 to $2 \mathrm{~mm}$ diameter aggregates, WAS2. These tests produced the same general result, although WAS2 had no interaction between grass species and depth (Table 1). In general, the plots with B. caucasica had the lowest wet aggregate stability and plots with $B$. ischaemum had the greatest wet aggregate stability (Tables 1 and 2). Plots with B. bladhii were not significantly different from plots with either of the other grass species. Often, within grass species, the surface 0 $5 \mathrm{~cm}$ had a greater wet stability than the $5-15 \mathrm{~cm}$ depth. Wet aggregate stability measured by WAS 8 had the same MWD with depth in plots with $B$. caucasica and the same percent stability with depth in plots with $B$. is
Table 2. Differences by depth among old world bluestem grass species for selected soil properties.

\begin{tabular}{cccccc}
\hline Grass Species Depth $(\mathrm{cm})$ & $\begin{array}{c}\text { SOC } \\
(\mathrm{g} / \mathrm{kg})\end{array}$ & $\begin{array}{c}\text { POC } \\
(\mathrm{g} / \mathrm{kg})\end{array}$ & $\begin{array}{c}\text { POC/SOC } \\
\text { Ratio }\end{array}$ & $\begin{array}{c}\text { MWD } \\
(\mathrm{mm})\end{array}$ \\
\hline B. caucasica & $0-5$ & $18.0 \mathrm{~b}$ & $9.1 \mathrm{~b}$ & $0.50 \mathrm{~b}$ & $5.43 \mathrm{bc}$ \\
B. baldhii & $0-5$ & $21.1 \mathrm{ab}$ & $13.2 \mathrm{a}$ & $0.63 \mathrm{a}$ & $5.65 \mathrm{ab}$ \\
B. ischaemum & $0-5$ & $22.0 \mathrm{a}$ & $12.7 \mathrm{a}$ & $0.57 \mathrm{ab}$ & $6.07 \mathrm{a}$ \\
B. caucasica & $5-15$ & $10.6 \mathrm{c}$ & $2.7 \mathrm{c}$ & $0.25 \mathrm{c}$ & $4.89 \mathrm{~cd}$ \\
B. baldhii & $5-15$ & $10.4 \mathrm{c}$ & $2.9 \mathrm{c}$ & $0.28 \mathrm{c}$ & $4.44 \mathrm{~d}$ \\
B. ischaemum & $5-15$ & $10.9 \mathrm{c}$ & $3.2 \mathrm{c}$ & $0.29 \mathrm{c}$ & $5.26 \mathrm{bc}$ \\
\hline
\end{tabular}

Notes: SOC-soil organic carbon, POC-particulate organic matter carbon, MWD-mean weight diameter of wet sieved aggregates. Values with the same letter within columns are not significantly different at the $P=0.05$ level.

chaemum. Wet aggregate stability measured as MWD or percent stability was significantly different by depth $(P<$ 0.05) in plots with B. bladhii (Table 2).

\subsection{Soil Chemical Properties}

Soil organic carbon and POC concentration $\left(\mathrm{g} \cdot \mathrm{kg}^{-1}\right)$ were each different between depths (Table 1). The greatest concentrations of SOC and POC were found in the surface $5 \mathrm{~cm}$, with about twice the amount of SOC in the surface as in the next $10 \mathrm{~cm}$ (Table 2). The mean SOC concentration for the surface $5 \mathrm{~cm}$ was $20.3 \mathrm{~g} \cdot \mathrm{kg}^{-1}$ $(\mathrm{SE}=0.46)$ and the $5-15 \mathrm{~cm}$ layer had $10.6 \mathrm{~g} \mathrm{~kg}^{-1} \cdot \mathrm{C}$ $(\mathrm{SE}=0.46)$. The mean POC concentration for the surface $5 \mathrm{~cm}$ was $11.7 \mathrm{~g} \cdot \mathrm{kg}^{-1}(\mathrm{SE}=0.20)$ and the $5-15 \mathrm{~cm}$ layer had $2.9 \mathrm{~g} \cdot \mathrm{kg}^{-1} \mathrm{C}(\mathrm{SE}=0.20)$. Soil with $B$. ischaemum had greater quantities of SOC and POC in the surface $0-5 \mathrm{~cm}$ than soils with $B$. caucasica, with no differences among species in the $5-15 \mathrm{~cm}$ depth (Table 2). Soils with B. bladhii had the same SOC and POC content as both other species (Tables 1 and 2).

When SOC and POC contents were computed on a mass per unit surface area basis, SOC content was different among grass species at the $P=0.1$ level while POC content was different among grass species at the $P$ $=0.05$ level (Table 1). Bothriochloa ischaemum had the greatest SOC and POC mass (MG.ha $\left.{ }^{-1}\right)$ and B. caucasica had the least SOC mass. The SOC mass observed in soil with B. bladhii was not different from either of the other grass species. The POC mass observed in soil with $B$. bladhii was not different from only $B$. ischaemum.

\subsection{Plant Biomass and Roots}

The above-ground plant biomass (herbage) of the grasses differed among species (Table 1). The least amount of herbage was produced by $B$. ischaemum, which had about one half the amount of above-ground biomass produced by $B$. caucasica and B. bladhii. Interestingly, this is the inverse of the amount of root biomass observed for each grass species. B. ischaemum had the 
greatest total root biomass in the 0 to $15 \mathrm{~cm}$ depth, whereas B. caucasica and B. bladhii had the least but similar amounts of root biomass (Table 1)

\section{DISCUSSION}

Soil texture can have a significant impact on soil properties that are important for crop growth. For example, a sandy clay loam soil will hold more plant available soil water than a sandy soil. In this study, although there were no differences in the surface sandy clay loam soil texture among grass species plots, we did observe statistical differences in the amount of primary soil particles such as clay content by soil depth (Table 1). However, the differences in clay and sand content among grass species were not practically different, with an absolute mean difference of only $1.2 \%$ and $2.4 \%$ for clay and sand, respectively. The similarity in texture of all plots suggests soil texture was not a factor in differences found in the other variables observed in this study.

Although there were no differences in surface soil texture among grass species, we did observe differences in plant growth. Bothriochloa caucasica and B. bladhii produced about twice the above-ground biomass with about $25 \%$ fewer roots than $B$. ischaemum. These results are consistent with previous research conducted within these plots showing lower aboveground biomass production of B. ischaemum than either B. bladhii or B. caucasica $[1,34]$. Although these grasses had been grazed or cut in the past, management was similar among these grasses and did not explain differences in productivity. The differences in plant properties seem to have contributed to the differences observed in soil properties.

The differences in root biomass among grass species may have produced differences in soil BD. The grass species plots with the higher soil bulk density (B. caucasica) also had the lowest root biomass. The BD values of plots with B. bladhii were not different from BD of the plots of the other grasses (Table 1). Lower BD in plots with more roots was expected because the mass per unit volume of roots is much lower than the mass per unit volume of the mineral soil material. In addition, when roots decompose they often leave pores that further contribute to a reduction in BD.

Plant roots also add carbon to the soil matrix as demonstrated in this study. The differences among plots in root mass paralleled the differences found in SOC. Bothriochloa ischaemum had the greatest root mass and SOC and POC and B. caucasica had the least. This trend is the inverse of the trend found in $\mathrm{BD}$, with $B$. ischaemum having the lowest $\mathrm{BD}$ and $B$. caucasica the greatest. This is consistent with many past studies where $\mathrm{BD}$ and SOC were inversely related $[30,46-48]$. This apparently anomalous result is explained by considering that roots contribute organic material to the soil matrix, causing SOC to increase, and also function to decrease the density as described above.

Soil resistance is strongly influenced by both soil water and bulk density $[49,50]$. Figure 1 shows the penetration resistance and soil water content measurements by grass species for the 0 to $30 \mathrm{~cm}$ depth. The ANOVA of penetration resistance in Table 1 was performed for only the 0 to $15 \mathrm{~cm}$ depth to correspond to the depths observed for bulk density. There were no differences in mean soil water content among grass species, although there were differences in soil water content by depth (Table 1). In addition, since there were no interactions of grass species with depth of soil water content, it was not considered a factor in affecting the BD and soil strength results.

The surface $0-5 \mathrm{~cm}$ had the greatest water content and lowest BD and soil strength. Soil BD and PR are quite variable but are often positively correlated [51]; however, B. ischaemum produced a higher PR than $B$. caucasica, which was the inverse of the mean soil BD observations. Rachman et al. [52] found a negative correlation of soil strength with BD. Although they did not use an in situ cone penetrometer test to measure soil strength as in our study, their soil strength test used a falling cone on intact soil cores and the results can be considered analogous. They interpreted their results to indicate that differences in soil strengths were related to differences in aggregate stability. They and others have concluded that soil management and cropping systems that accumulate organic matter which, in turn, reduce the soil's vulnerability to slaking and dispersion on wetting, increase the soil's resistance to penetration by a dropped cone $[52,53]$.

This relation of soil strength and aggregate stability is supported by our results of the wet aggregate stability tests described in Tables $\mathbf{1}$ and 2. The tests showed that, similar to the trends shown for PR, the aggregate stability of $B$. ischaemum (WAS2) was significantly greater than the stability of $B$. caucasica. The wet aggregate stability (WAS2) in B. bladhii was not different from the other grasses (Table 1). Additionally, the tests showed that $B$. ischaemum broke down into larger aggregates upon wetting (MWD in Table 2), suggesting greater stability. Differences in wet aggregate stability with depth shown in Table 2 are complicated but, in general they show greater stability for the less dense and resistant surface layer.

Many studies have shown a positive correlation of SOC and aggregate stability $[22,52,54,55]$. In this study, the trends in SOC and POC mass followed those found for wet aggregate stability; $B$. ischaemum had a greater SOC and POC mass than B. caucasica, and the SOC 
mass for B. bladhii was not different from either of the other grasses (Table 1). As mentioned earlier, the greater values for SOC and POC mass are attributed to the greater root biomass found in the soil of the $B$. ischaemum treatment (Table 1). The greater root biomass produced more carbon and root structures and chemical binding agents to improve the wet aggregate stability found in the soil of the $B$. ischaemum treatment. Figure 2 illustrates the similar trends of wet aggregate stability, SOC content, and root biomass.

Studies suggest that POC is more sensitive to changes in management than changes in total SOC $[17,18,56]$. This is attributed to the faster turnover rate of POC compared with SOC [17,30]. An Australian Vertisol lost organic carbon upon conversion from pasture to cropland with $70 \%$ of the loss in SOC coming from POC [57]. The POC/SOC ratio has been used to indicate differences among locations of grass communities in the Argentinean Pampa [30]. Noellemeyer et al. [30] found a ratio of 0.54 for communities in the shade and 0.39 for communities in the sun. All of our plots were in full sun. We found differences in the POC/SOC ratio in the surface $0-5 \mathrm{~cm}$ among bluestem species that paralleled the findings of the individual SOC and POC results (Table 2). Bothriochloa caucasic had a POC/SOC ratio of 0.50 while B. bladhii had a significantly greater ratio of 0.63 . The POC/SOC ratio of plots with $B$. ischaemum was not different from the ratios of the plots of the other grasses (Table 2). The SOC and POC values were much lower for the $5-15 \mathrm{~cm}$ layer causing the $\mathrm{POC} / \mathrm{SOC}$ ratios to be about on half that of the surface $5 \mathrm{~cm}$. The SOC in the second layer was about on half that of the

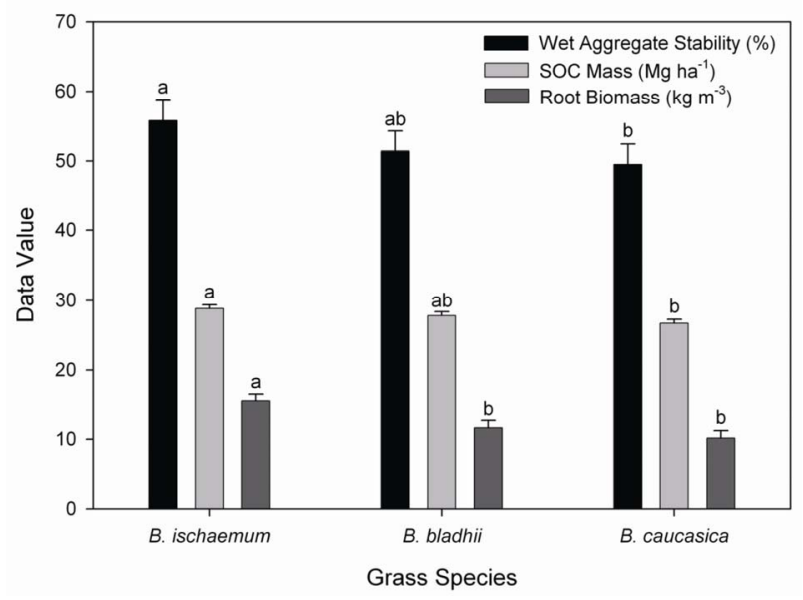

Figure 2. Wet aggregate stability (1 - $2 \mathrm{~mm}$ diameter, \%), soil organic carbon (SOC) mass $\left(\mathrm{MG}^{\circ} \mathrm{ha}^{-1}\right)$ and root biomass $\left(\mathrm{kg} \cdot \mathrm{m}^{-3}\right)$ by grass species. Means with the same letter, by data type, are not significantly different at the $P=0.05$ lever for wet aggregate stability and root biomass and at the $P=0.10$ level for SOC mass. surface while the POC of the second layer was from about one quarter to one third that of the surface layer, supporting a faster turnover rate for the $\mathrm{POC}$ in this study.

Since SOC is a key attribute of soils that impacts erosion control, soil structure, water infiltration, conservation of nutrients and other soil properties, the stratification of SOC has been proposed as a simple diagnostic tool to identify land management strategies that improve soil properties $[58,59]$. In a study comparing plots under long-term conventional and no-tillage, Franzluebbers [59] found the stratification of SOC at shallow depths (the ratio of the SOC at $0-3 \mathrm{~cm}$ depth divided by that of 6 $12 \mathrm{~cm}$ depth) increased as water infiltration rate and wet stability (as measured by the MWD) increased and was inversely related to BD and PR. Thus, the SOC stratification ratio (SOCSR) tended to increase with soil properties indicating increasing soil quality for plant growth. In our study, the SOCSR was determined as the ratio of the SOC at $0-5 \mathrm{~cm}$ depth divided by that of $5-15 \mathrm{~cm}$ depth. Bothriochloa caucasic had a mean SOCSR of 1.70 (using data provided in Table 2) while B. bladhii and $B$. ischaemum were the same, with SOCSRs of 2.03 and 2.02, respectively. These ratios are similar to SOCSRs observed in a study of a silty clay loam soil under no tillage management in south central Texas [58]. Although we did not discern differences in water infiltration among grass species in this study, the trends of SOCSR with the MWD of the 0 - $5 \mathrm{~cm}$ depth, bulk density, and penetration resistance were similar to those reported by Franzluebbers [59]. Bothriochloa caucasic had the lowest SOCSR, suggesting a lower soil quality than B. bladhii and B. ischaemum, which were the same.

\section{SUMMARY AND CONCLUSIONS}

Several Old World Bluestem grass species are commonly used in the Southern High Plains in forage management systems and as conservation reserve grasslands species. Although studies have identified differences in growth and production among these species, little is known about how they affect soil properties. The results of this study support the hypothesis that differences in grass species produce differences in soil properties. The grass species differed in their above-ground biomass and below-ground root production. Bothriochloa caucasica and $B$. bladhii produced about twice the above-ground biomass with about $25 \%$ less root mass than $B$. ischaemum. This may help to explain observed differences in plant persistence under dryland conditions. The greater root biomass of the $B$. ischaemum also produced a lower soil bulk density than the other species. Although we expected that the density would affect soil strength, this was not the case. Although the soil in which $B$. ischae- 
mum was growing had a lower bulk density, it had the greatest soil strength. The soil strength was greatest in $B$. ischaemum, which also had the greatest root biomass, organic matter content, and aggregate stability. These three characteristics are related. The root biomass increases the organic matter of the soil. The organic matter provides energy for microbial populations and other soil fauna which produce materials that bind soil particles into aggregates. In addition, roots may provide additional particle aggregation through effects of root exudates and very small root structures.

The species B. bladhii usually exhibited desirable soil properties that were similar to both other species tested. Since Bothriochloa bladhii also has been shown to be higher in forage quality, animal performance, and carrying capacity than $B$. ischaemum, it appears to be the best choice among these three species to optimize both animal performance and desirable soil properties.

\section{ACKNOWLEDGMENTS}

The authors are indebted to Dean Holder (USDA ARS) and Deanna Halfmann Faubian (formerly USDA ARS, currently USDA NRCS) for technical assistance with field work and laboratory analyses.

\section{NOTES}

Mention of this or other proprietary products is for the convenience of the readers only, and does not constitute endorsement or preferential treatment of these products by USDA-ARS. USDA is an equal opportunity provider and employer.

\section{REFERENCES}

[1] Philipp, D., Allen, V.G., Mitchell, R.B., Brown, C.P. and Wester, D.B. (2005) Forage nutritive value and morphology of three old world bluestems under a range of irrigation levels. Crop Science, 45, 2258-2268. doi:10.2135/cropsci2004.0669

[2] Dewald, C.L., Sims, P.L. and Berg, W.A. (1995) Registration of 'WW-B. Dahl' old world bluestem. Crop Science, 35, 937. doi:10.2135/cropsci1995.0011183X003500030055x

[3] Sanderson, M.A., Voigt, P. and Jones, R.M. (1999) Yield and quality of warm-season grasses in central Texas. Journal of Range Management, 52, 145-150. doi: $10.2307 / 4003508$

[4] Coyne, P.I., Bradford, J.A. and Dewald, C.L. (1982) Leaf water relations and gas exchange in relation to forage production in four Asiatic bluestems. Crop Science, 22, 1036-1040. doi:10.2135/cropsci1982.0011183X002200050034x

[5] Coyne, P.I. and Bradford, J.A. (1985) Some growth characteristics of four old world bluestems. Journal of Range Management, 38, 27-33. doi:10.2307/3899327

[6] Coyne, P.I. and Bradford, J.A. (1986) Biomass partitioning in 'Caucasion' and WW-Spar; old world bluestems. Journal of Range Management, 39, 303-310. doi: $10.2307 / 3899768$

[7] Philipp, D. (2004) Influence of varying replacement of potential evapotranspiration on water use efficiency and nutritive value of three old world bluestems (Bothriochloa spp.). Ph.D. Dissertation, Texas Tech University, Lubbock.

[8] Philipp, D., Brown, C.P., Allen, V.G. and Wester, D.B. (2006) Influence of irrigation on mineral concentrations in three old world bluestem species. Crop Science, 46, 2033-2040. doi:10.2135/cropsci2005.11.0422

[9] Allen, V.G., Brown, C.P., Segarra, E. Green, C.J., Wheeler, T.A., Acosta-Martinez, V. and Zobeck, T.M. (2008) In search of sustainable agricultural systems for the Llano Estacado of the U.S. southern high plains. Agriculture, Ecosystems \& Environment, 124, 3-12. doi:10.1016/j.agee.2007.08.006

[10] Machado, S., Rhinhart, K. and Petrie, S. (2006) LongTerm cropping system effects on carbon sequestration in eastern Oregon. Journal of Environmental Quality, 35, 1548-1553. doi: $10.2134 /$ jeq2005.0201

[11] Cambardella, C.A. and Elliott, E.T. (1994) Carbon and nitrogen dynamics of soil organic matter fractions from cultivated soils. Soil Science Society of America Journal, 58, 123-130. doi:10.2136/sssaj1994.03615995005800010017x

[12] McHenry, J. and Newell, L.C. (1947) Influence of some perennial grasses on the organic matter content and structure of an eastern Nebraska fine-textured soil. Agronomy Journal, 39, 981-994. doi:10.2134/agronj1947.00021962003900110005x

[13] Collins, H.P., Rasmussen, P.E. and Douglas, C.L. (1992) Crop rotation and residue management effects on soil carbon and microbial dynamics. Soil Science Society of America Journal, 56, 783-788. doi:10.2136/sssaj1992.03615995005600030018x

[14] Filho, C.C., Lourenço, A., de Guimarães, F.M. and Fonseca, I.C.B. (2002) Aggregate stability under different soil management systems in a red latosol in the state of Parana, Brazil. Soil and Tillage Research, 65, 45-51. doi:10.1016/S0167-1987(01)00275-6

[15] Liebig, M.A., Tanaka, D.L. and Wienhold, B.J. (2004) Tillage and cropping effects on soil quality indicators in the northern Great Plains. Soil and Tillage Research, 78, 131-141. doi:10.1016/j.still.2004.02.002

[16] Bronick, C.J. and Lal, R. (2005) Soil structure and management: A review. Geoderma, 124, 3-22. doi:10.1016/j.geoderma.2004.03.005

[17] Cambardella, C.A. and Elliott, E.T. (1992) Particulate soil organic-matter changes across a grassland cultivation sequence. Soil Science Society of America Journal, 56, 777-783. doi:10.2136/sssaj1992.03615995005600030017x

[18] Potter, K.N. and Derner, J.D. (2006) Soil carbon pools in central Texas: Prairies, restored grasslands, and croplands. Journal of Soil and Water Conservation, 61, 124-128.

[19] Zobeck, T.M., Crownover, J., Dollar, M., van Pelt, R.S., Acosta-Martinez, V., Bronson, K.F. and Upchurch, D.R. (2007) Investigation of soil conditioning index values for southern high plains agrecosystems. Journal of Soil and Water Conservation, 62, 433-442.

[20] Wander, M.M., Bidart, M.G. and Aref, S. (1998) Tillage impacts on depth distribution of total and particulate or- 
ganic matter in three Illinois soils. Soil Science Society of America Journal, 62, 1704-1711. doi:10.2136/sssaj1998.03615995006200060031x

[21] Perfect, E., Kay, B.D., van Loon, W.K.P., Sheard, R.W. and Pojasok, T. (1990) Rates of change in soil structure stability under forages and corn. Soil Science Society of America Journal, 54, 179-186. doi:10.2136/sssaj1990.03615995005400010028x

[22] Tisdall, J.M. and Oades, J.M. (1982) Organic matter and water stable aggregates in soils. Journal of Soil Science, 33, 141-163. doi:10.1111/j.1365-2389.1982.tb01755.x

[23] Goulet, E., Dousset, S., Chassod, R., Bartoli, F., Doldec, A.F. and Andreux, F. (2004) Water-Stable aggregates and organic matter pools in a calcareous vineyard soil under four soil-surface management systems. Soil Use and Management, 20, 318-324. doi:10.1111/j.1475-2743.2004.tb00376.x

[24] Haynes, R.J. and Beare, M.H. (1997) Influence of six crop species on aggregate stability and some labile organic matter fractions. Soil Biology and Biochemistry, 29, 1647-1653.

[25] Wuest, S.B. Williams, J.D and Gollany, H.T. (2006) Tillage and perennial grass effects on ponded infiltration for seven semi-arid loess soils. Journal of Soil and Water Conservation, 61, 218-222.

[26] Drury, C.F., Stone, J.A. and Findlay, W.I. (1991) Microbial biomass and soil structure associated with corn, grasses, and legumes. Soil Science Society of America Journal, 55, 805-811. doi:10.1016/S0038-0717(97)00078-3

[27] Carter, M.R., Angers, D.A. and Kunelius, H.T. (1994) Soil structural form and stability, and organic matter under cool-season perennial grasses. Soil Science Society of America Journal, 58, 194-1199. doi:10.2136/sssaj1994.03615995005800040027x

[28] Fryrear, D.W. and McCully, W.G. (1972) Development of grass root systems as influenced by soil compaction. Journal of Range Management, 25, 254-257. doi:10.2307/3896905

[29] Benjamin, J.G., Mikha, M., Nielsen, D.C., Vigil, M.F., Calderon, F. and Henry, W.B. (2007) Cropping Intensity effects on physical properties of a no-till silt loam. Soil Science Society of America Journal, 71, 1160-1165. doi:10.2136/sssaj2006.0363

[30] Noellemeyer, E., Quiroga, A.R. and Estelrich, D. (2006) Soil quality in three range soils of the semi-arid Pampa of Argentina. Journal of Arid Environments, 65, 142-155. doi:10.1016/j.jaridenv.2005.07.007

[31] Acosta-Martinez V., Zobeck, T.M. and Allen, V. (2004) Soil microbial, chemical and physical properties in continuous cotton and integrated crop-livestock systems. Soil Science Society of America Journal, 68, 1875-1884. doi:10.2136/sssaj2004.1875

[32] Ferrero, A., Usowicz, B. and Lipiec, J. (2005) Effects of tractor traffic on spatial variability of a soil strength and water content in a grass covered and cultivated sloping vineyard. Soil and Tillage Research, 84, 127-138. doi:10.1016/j.still.2004.10.003

[33] Maestre, F.T., Huesca, M., Zaady, E., Bautista, S. and Cortina, J. (2002) Infiltration, penetration resistance and microphytic crust composition in contrasted microsites within a Mediterranean semi-arid steppe. Soil Biology and Biochemistry, 34, 895-898 doi:10.1016/S0038-0717(02)00021-4

[34] Philipp, D., Allen, V.G., Lascano, R.J., Brown, C.P. and Wester, D.B. (2007) Production and Water Use Efficiency of Three Old World Bluestems. Crop Science, 47, 787-794. doi:10.2135/cropsci06.05.0340

[35] Niemann, D., Allen, V. and Brown, C. (2001) Potential of old world bluestems and lovegrass for grazing lambs in the southern high plains. Annual Meeting Abstracts American Society of Agronomy, Crop Science Society of American, Soil Science Society of American, Charlotte.

[36] Allen, R.G., Pereira, L.S., Raes, D. and Smith, M. (1998) Crop evapotranspiration. FAO Irrigation and Drainage Paper 56, FAO, Rome.

[37] United States Department of Agriculture, Natural Resources Conservation Service (USDA, NRCS) (2010) NRCS geographic extent mapping tool.

http://www.cei.psu.edu/soiltool/semtool.html?seriesname $=$ PULLMANUH

[38] Zobeck, T.M. (2004) Rapid particle size analyses using laser diffraction. Transaction of the American Society of Agricultural Engineers, 20, 633-63.

[39] Blake, G.R. and Hartge, K.H. (1986) Bulk density. In: Klute, E., Ed., Methods of Soil Analysis, 2nd Edition, American Society of Agronomy-Soil Science Society of America, Madison, 363-382.

[40] American Society of Agricultural Engineers (ASAE) (2006) Procedures for using and reporting data obtained with the soil cone penetrometer. St. Joseph, Michigan, 1052-1055.

[41] Bower, H. (1986) Intake rate: Cylinder infiltration. In: Klute, E., Ed., Methods of Soil Analysis, $2^{\text {nd }}$ Edition, American Society of Agronomy and Soil Science Society of America, Madison, 825-844.

[42] Kemper, W.D. and Rosenau, R.C. (1986) Aggregate stability and size distribution. In: Klute, A., Ed., Methods of soil analysis, $2^{\text {nd }}$ Edition, American Society of Agronomy and Soil Science Society of America, Madison, 425-442.

[43] Kemper, W.D. (1965) Aggregate stability. In: Black, C.A., et al., Eds., Methods of soil analysis, $2^{\text {nd }}$ Edition, American Society of Agronomy and Soil Science Society of America, Madison, 511-519.

[44] Gregorich, E.G. and Ellert, B.H. (1993) Light fraction and macroorganic matter in mineral soils. In: Carter, M.R., Ed., Soil Sampling and Methods of Analysis, Lewis Publishers, Boca Raton, 397-407.

[45] SAS-Institute (2002) The SAS system for Windows, version 9.1. SAS Institute, Cary.

[46] Wienhold, B.J., Hendrickson, J.R and Karn, J.F. (2001) Pasture management influences on soil properties in the northern Great Plains. Journal Soil and Water Conservation, 56, 27-31.

[47] Soussana, J.-F., Loiseau, P., Vuichard, N., Ceschia, E., Balesdent, J., Chevallier, T. and Arrouays, D. (2004) Carbon cycling and sequestration opportunities in temperate grasslands. Soil Use and Management, 20, 219230. doi:10.1079/SUM2003234

[48] Steffens, M., Kölbl, A., Totsche, K.U. and Kögel-Knabner, I. (2008) Grazing effects on soil chemical and physical properties in a semiarid steppe of Inner Mongolia (P.R. China). Geoderma, 143, 63-72. doi:10.1016/j.geoderma.2007.09.004 
[49] Cassel, D.K. (1982) Tillage effects on soil bulk density and mechanical impedance. In: Unger, P.W. and van Doren, J.D.M., Eds., Predicting tillage effects on soil physical properties and processes, American Society of Agronomy and Soil Science Society of America, Madison, 45-67.

[50] Da Silva, A.P. and Kay, B.D. (1997) Estimating the least limiting water range of soils from properties and management. Soil Science Society of America Journal, 61, 877-883.

doi:10.2136/sssaj1997.03615995006100030023x

[51] Kaufmann, M., Tobias, S. and Schulin, R. (2009) Development of the mechanical stability of a restored soil during the first 3 years of re-cultivation. Soil and Tillage Research, 103, 127-136. doi:10.1016/j.still.2008.10.002

[52] Rachman, A., Anderson, S.H., Gantzer, C.J and Thompson, A.L. (2003) Influence of Long-term Cropping Systems on Soil Physical Properties Related to Soil Erodibility. Soil Science Society of America Journal, 67, 637-644. doi:10.2136/sssaj2003.0637

[53] Ekwue, E.I. (1990) Organic-matter effects on soil strength properties. Soil and Tillage Research, 16, 289297. doi:10.1016/0167-1987(90)90102-J

[54] Angers, D.A. (1998) Water-Stable aggregation of Quebec silty clay soils: Some factors controlling its dynamics. Soil and Tillage Research, 47, 91-96.

doi:10.1016/S0167-1987(98)00077-4

[55] Chenu, C., le Bissonnais, Y. and Arrouays, D. (2000) Organic matter influence on clay wetability and soil aggregate stability. Soil Science Society of America Journal, 64, 1479-1486. doi:10.2136/sssaj2000.6441479x

[56] Wander, M.M. and Bidart, M.G. (2000) Tillage practice influences on the physical protection, bioavailability and composition of particulate organic matter. Biology and Fertility of Soils, 32, 360-367. doi:10.1007/s003740000260

[57] Chan, K.Y. (1997) Consequences of changes in particulate organic carbon in vertisols under pasture and cropping. Soil Science Society of America Journal, 56, 777783.

[58] Franzluebbers, A.J. (2002) Soil organic matter stratification ratio as an indicator of soil quality. Soil and Tillage Research, 66, 95-106. doi:10.1016/S0167-1987(02)00018-1

[59] Franzluebbers, A.J. (2002) Water infiltration and soil structure related to organic matter and its stratification with depth. Soil and Tillage Research, 66, 197-205. doi:10.1016/S0167-1987(02)00027-2 